This is a self-archived - parallel published version of this article in the publication archive of the University of Vaasa. It might differ from the original.

\title{
From slow repetition to awkward omission: Economic, efficient, and precise language use in bilingual formal meetings
}

\author{
Author(s): Koskela, Merja; Pilke, Nina \\ Title: From slow repetition to awkward omission: Economic, efficient, \\ and precise language use in bilingual formal meetings \\ Year: $\quad 2016$ \\ Version: Publisher's pdf \\ Copyright De Gruyter
}

Please cite the original version:

Koskela, M. \& Pilke, N. (2016). From slow repetition to awkward omission: Economic, efficient, and precise language use in bilingual formal meetings. Multilingua, 35(3), 215-275. https://doi.org/10.1515/multi-2014-0075 


\section{Merja Koskela* and Nina Pilke \\ From Slow Repetition to Awkward Omission: Economic, Efficient, and Precise Language Use in Bilingual Formal Meetings}

Abstract: This article explores how linguistic resources from two local languages, Finnish and Swedish, are used in expert presentations in bilingual formal meetings and how they function with respect to the three ideal criteria of professional communication: economy, efficiency, and precision. Based on the results, the article suggests a typology of bilingual action for bilingual formal meetings. While economic language use has to do with the time used for getting something done, efficiency, covers relevant, concise, and focused language use and precision is connected with ways of presenting a full depiction of the issues discussed. The typology suggests six types of bilingual action that interact closely depending on the context. The findings underline the importance of documentation and open discussion of organization-level practices in guiding bilingual action as an intentional and goal-oriented practice in professional contexts. The typology of bilingual action suggested in this article can be used when introducing the practices of bilingual meetings to new participants.

Keywords: formal meeting, bilingual action, professional communication, economy, efficiency, precision

\section{Introduction}

The current article explores professional communication in a context of bilingual formal meetings. In order to do this, the article focuses on how meeting participants utilize two local languages, Finnish and Swedish in organizing and coordinating their actions, and how they experience the use of language in these encounters.

*Corresponding author: Merja Koskela, Department of Communication Studies, University of Vaasa, Vaasa, Finland, E-mail: merja.koskela@uva.fi

Nina Pilke, Department of Scandinavian Languages, University of Vaasa, Vaasa, Finland, E-mail: nina.pilke@uva.fi 
Professional communication has its own specific contextual affordances, including field-specific discourses, genres, conceptualizations, and social and cultural practices. According to a recent definition by Schnurr (2013: 17), professional communication is a term used for communicative encounters in a context broadly related to work where at least one participant is engaged in some workrelated activity. These encounters consist of both transactional communicative features that aim to get things done and relational features intended to enhance interpersonal relationships and create a positive atmosphere (Schnurr 2013: 9). From the transactional point of view, professional communication is directed by the ideal criteria set for successful communication. Among the models describing such criteria, Engberg's (1998: 29-30) model, based on Fluck (1991), encompasses four criteria. According to this model, successful professional communication is based on language use that is unambiguous, precise, economic, and usable. In the model, unambiguousness stands for monosemy, one term for one concept, whereas economy concerns the brevity of expression when using terms. Precision concerns the way of dividing reality into concepts in different ways in different disciplines, and usability refers to addressing the intended audience in a way that is easy for them to understand. In comparison, models that list criteria for successful expert-to-non-expert communication pay more attention to relational aspects. Among others, Koskela (2002: 29) recommends that expert knowledge should be presented to non-experts so that it is interesting, entertaining, understandable, correct, and relevant.

Meetings are typical sites of multilingual workplace communication, where both transactional and relational features of professional communication work side by side. Therefore, they have offered a fruitful basis for the study of many communicational phenomena. With regard to multilingualism in meetings, existing research has concentrated on code-switching, for example, as a power tool or as a means of problem solving (Jan 2003; Mondada 2004; Nikko 2009). More generally, the results of research on multilingualism in the workplace tend to highlight the relationship between local and global languages and their asymmetry that in practice may lead to social exclusion (see, e.g., Angouri 2014; Gunnarsson 2014).

The aim of this article is to describe which types of bilingual action in expert presentations best serve the purposes of successful professional communication in bilingual formal meetings. Based on the results, we will suggest a typology of bilingual action for this context. We will concentrate on expert presentations because they represent professional communication as the speakers are operating in their expert-roles. What is more, they consume a large portion of the meeting time and form a basis for discussions, which is why bilingual action is required to ensure all participants the opportunity to understand the contents and 
participate in the ensuing debate. For the context of this article, we define the concept of bilingual action as those communicative choices that the meeting participants, especially the chairperson and experts, make when going through a paragraph using two local languages in a way that makes professional communication functional and enables both language groups to participate. For example, an expert might show a PowerPoint slide in one language and speak in the other language. Such communicative choices reflect societal, situational, social, and individual factors resulting in a rich dynamism of different types of bilingual action and combinations of them, which make the topic worth studying.

Typologies can be based on different criteria. For example, bilingual action may be categorized according to the semiotic resources used, the time allotted to each language, the language(s) used within a turn, the inter-discursive features, as well as the meanings delivered. In this article, we structure the discussion of the typology of bilingual action according to three criteria of successful professional communication. These criteria draw from Engbergs's model but we develop it further for the purposes of this study. The criteria used here are economy, precision and efficiency (for definitions see Section 6). This means the current research offers new information on the prerequisites of bilingual professional communication, because it helps to explain what is possible, what functions, and what might be the optimal course of action in a certain context.

\section{The role and status of Finnish and Swedish in Finnish society}

Finnish and Swedish are the national languages in Finland and are of equal status. The organization and use of the languages is regulated by The Language Act of Finland (423/2003) and several other acts. For example, according to the Language Act, every person has a right to use his or her own language, either Finnish or Swedish, before courts and other authorities. Accordingly, a member of an organ of a bilingual municipality has the right to use Finnish or Swedish in a meeting. If another member of the body does not understand an oral statement, it will be explained to him or her briefly on request.

The prevailing language ideology in Finnish society is that of institutional language separation in which schools, media and cultural institutions, for example, are language-specific (see, e.g., Fishman 1972; Gafaranga 2000; Creese et al. 2011). In spite of the politics of language separation, there are many fora, such as in democratic decision-making; where for practical reasons the two languages are brought together into the same arena. However, according 
to some experts, monolingual institutions are the only way to defend language minorities' rights, especially if the minority is small. When there is an asymmetrical majority-minority-relation, bilingual situations may easily turn monolingual under the domination of the majority language (see, e.g., Liebkind et al. 2007; Mougeon \& Beniak 1994; Giles et al. 1977.)

Regarding Swedish in Finland, the majority-minority relationship varies regionally. In the whole country (population 5.4 million), 5.4\% of the population are registered as Swedish speakers and $90 \%$ as Finnish speakers. This makes Swedish a rather small national language. In contrast, however, in the region of Ostrobothnia, with a population of about $180,000,50 \%$ of the inhabitants are Swedish speaking, 45\% Finnish speaking, and 5\% speak other languages (Pohjanmaa lukuina 2013). The region of Ostrobothnia thus has a linguistic profile in which the two national languages stand in a relation more symmetrical than asymmetrical. Nevertheless, although Swedish is the majority language in the region, many administrative and workplace practices there are influenced by the national position of Swedish. For example, government documents used in formal meetings are translations from Finnish and they may arrive in the regions late or only in Finnish (Pilke \& Salminen 2013: 75).

The symmetrical relationship between the two languages within the region may offer alternative ways of using bilingual and multilingual linguistic resources in professional communication. These may also be applied in more asymmetrical contexts. It can be assumed that the symmetrical relationship promotes balanced linguistic practices in regional meetings. If an institution at a strategic level chooses to function bilingually or multilingually, everyday practices must be organized accordingly. This requires goal orientation at the organizational level, and greater awareness of linguistic requirements and alternative linguistic practices in each situation, while still leaving room for intuitive creative solutions. Even though a bilingual society might be based on two parallel monolingualisms with separate institutions, a functioning society requires that in questions of common interest the two languages are brought into the same forum. Such fora should be based on multilingual resources in order to guarantee participation and offer a sense of inclusion (see Vasilev 2013).

\section{Data}

This study is based on three types of data concerning four meetings held by the Regional Co-operation Group of Ostrobothnia. This organ is responsible for the development of the region, and especially the national administration of EU structural fund programs at a regional level. It has 25 members representing 
municipalities, government authorities, and local organizations. The first part of the data consists of 6 hours and 51 minutes of recordings from meetings held between April 2010 and February 2011. On average, each meeting lasted about an hour and a half and had 18-25 participants.

The second part of the data comprises the meeting documents in two languages. These include the agenda and the supporting documents sent to the participants before the meeting and the PowerPoint presentations shown in the meetings. The third type of data stems from a brief questionnaire sent to the members of the Regional Cooperation Group in autumn 2011 asking for their views on their language skills and on the functioning of the meetings as bilingual events; the request produced 21 completed questionnaires (for more details see Pilke \& Salminen 2013).

In current meeting research, the term meeting is polysemic. Very different types of social encounters have been studied in the name of meeting-research, including interviews, team and department meetings, negotiations, management meetings, and public service meetings (Asmuss \& Svennevig 2009). In this study, we define a meeting as a communicative event involving three or more people who agree to assemble for a purpose, who engage in episodic multiparty talk and follow specific conventions (see also Schwartzman 1989; Boden 1994: 84). A characteristic feature of meetings is also their varying degree of formality.

Formal meetings are based on an official mandate given to the body holding the meetings, for instance by law or an agreement. A formal meeting is a meeting organized regularly with a nominated chairperson and secretary, with experts presenting issues and elected nominated participants with predefined institutional roles dealing with the issues. Formal meetings are planned in advance, there is a predetermined written agenda and meeting documents are sent to the participants in advance, and the event is documented in the form of minutes (see, e.g., Asmuss \& Svennevig 2009; Angouri \& Marra 2010: 619).

Bilingual and multilingual meetings where two or more languages are spoken can be organized with or without interpretation. A bilingual formal meeting in this research is a formal meeting without interpretation where Finnish and Swedish are spoken and where the agenda and supporting documents are in two languages. In the meeting, the chairperson and experts use both languages, whereas the participants may use their own language. Interestingly, there are no explicit instructions for how bilingual action is to be carried out in the meetings.

Formal meetings follow a strict internal structure as depicted in Figure 1. In general, organizing a meeting can be divided into three phases: pre-meeting (including agenda planning, practical preparations), the meeting proper (including preliminaries, the processing of issues, and closing) and post-meeting (including compiling and checking the minutes and follow-up) (see Bargiela- 


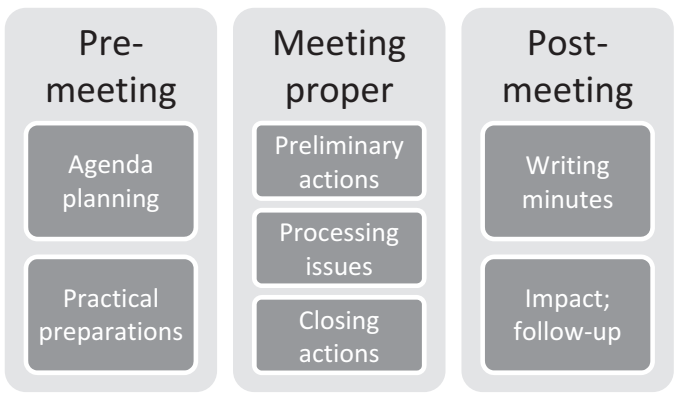

Figure 1: The structure of a formal meeting

Chiappini \& Harris 1997). In a bilingual formal meeting, the linguistic profile may vary depending on the phase of the meeting proper (see Mondada 2004: 21). The same applies within each paragraph, the processing of which generally follows a structure of its own: opening by the chairperson, presentation by an expert, discussion by the participants, eventual voting, and closing by the chairperson (see also Angouri \& Marra 2010: 619).

\section{Method}

The method of this study is based on a qualitative analysis concentrating on which types of bilingual action serve the purposes of three chosen criteria for successful professional communication. For background, we will also present some quantitative characterizations of how the two languages are used in meetings.

The starting point of the analysis is the concept of turn understood as a form-based unit starting when a speaker is given a turn, and she or he accepts it, and ending when the speaker displays a cue of some type indicating they are yielding the turn (see, e.g., Duncan 1972; Linell \& Gustavsson 1987: 14). In the expert presentations, turns are typically yielded explicitly by the experts themselves for example by asking for questions (“Any questions?”), by simply stating that the presentation is over ("I am ready"; "This completes my part", "That was all I was going to say") or by thanking the audience ("Yes, thank you."; "Thanks"). It must be remembered that in the institutional context of a formal meeting, transitions between turns do not take place spontaneously but on request. Consequently, as in other institutional settings (see, e.g., Drew \& Sorjonen 1996: 197-198), there is very little overlap and no competing in taking a turn. In our analysis, the rare cases of overlaps do not constitute turns because 
they function as acknowledgments and do not imply that the speaker wants to take their turn (about competitive and non-competitive overlaps, see Sacks et al. 1974; Jefferson 1983). The back-channel cues are listener responses showing the listeners' interest (see White 1997; Ishida 2006: 1945; see also Duncan 1972). In this professional context, it is those turns offered that contribute to the processing of the issue.

In total, our material includes 19 expert presentations, of which 17 are bilingual and 1 is monolingual in Finnish and 1 in Swedish. Because the turns presented by the experts in the meetings studied are lengthy, for practical reasons we segmented them further. In our analysis, we have used the same structuring principle as the person giving the presentation. Based on our material, most of the speakers structure their presentation by referring to a point in a text by mentioning a page number or a heading or to a slide in a PowerPoint presentation. This structural, but simultaneously content-based segmentation enables us to see how the whole is constituted from its parts. This type of segmentation results in structural passages of different lengths that can be monolingual or bilingual. As such, the passages serve a purpose or an intention on the part of the speaker (see, e.g., Taboada \& Hadic Zabala 2008: 67). Our interest lies particularly in how bilingual action evolves in these passages in an optimal way from the point of view of professional communication. Following the idea presented by Ford et al. (1996), we concentrate on the practices of forming turns and making them interpretable. Therefore, we will look at the content within these passages and compare the content expressed in each of the two languages.

The different types of bilingual action within the passages in the expert presentations are identified through two language-related concepts, namely turn constructional components (TCC) and/or turn constructional units (TCU). According to Sacks et al. (1974), TCC is the term used for the resources for building a turn in interaction. A TCC in this study is a pair of interactionally relevant, complete linguistic units in different languages sharing essentially the same content. In our analysis, we also use a language-based definition for the concept of the TCU, even though it is traditionally syntactically (Sacks et al. 1974) and prosodically (Ford \& Thompson 1996) determined and collaboratively constructed. Consequently, a TCU in our analysis may be a section, a sentence, or a clause understood as the smallest interactionally relevant complete linguistic unit (see Selting 2000). In conversation analytical discussions, long turns such as telling stories have been challenging to segment, because of the issues involved in defining what constitutes a TCU in different contexts. For example, Selting (2000: 485) states that a story can constitute one single TCU or alternatively, stories could be analyzed based on syntactic units, that is, sentences, clauses, phrases and so on treated as a TCU. Selting (2000: 485) claims that large TCUs need to be segmented into 
smaller units in order to be analyzed, but does not name or define what the smaller units should be. In our analysis, a TCU is the smallest unit and it may be monolingual or bilingual as long as the unit is interactionally relevant in its context. A TCU ends when the speaker changes language or when a TCC ends. In our analysis, we need both a TCU and TCC because the stretches expressed in each language can be of different lengths and not all that is said in one language is expressed in the other. For example, a TCC might include two sentences with the same content but expressed in different languages, or a longer explanation in one language and a shorter summary in the other. What is more, a TCU in one language need not be expressed in the other language at all.

The largest segment is the paragraph (§), which is always bilingual. The next level is that of the turn, which can have any of the linguistic profiles, as can the passage. TCCs are optional and are always bilingual, whereas TCUs can be either monolingual or bilingual.

In this article, we will focus on three ideal criteria for successful professional communication: economy, precision, and efficiency. These three criteria capture the essence of the affordances and challenges of professional communication and (despite some overlap) can be separated from each other. First, economic language use in the meetings results in the transactional goal of accomplishing the desired outcome in the shortest possible time. Second, efficient language use leads to relevant, concise, and focused discussions. Third, precise language use attends to detail, and therefore guarantees the best possible depiction of the issues for all the participants. It is evident that these criteria may well conflict; for example, being economic and precise at the same time is a theoretical ideal for transactional communication. The best possible balance between these ideals is constantly sought in practical situations of professional communication by using a variety of linguistic resources, some of which are intrinsic features of specialized language, whereas others require improvisation. In addition, bilingual formal meetings without interpretation present a highly specific professional context, because they require that the balancing and improvisation be carried out in two languages.

During the analysis, we first identify the types of bilingual action used in order to achieve functional professional communication in the meeting context and then discuss their potential to serve the ideal criteria. In the next step, we scrutinize how the types relate to each other and how they are intertwined in the dynamics of the language use in the meetings. In the analysis, we refer to the meeting documents when they are relevant to understanding and interpreting the examples presented. We also use the results of the questionnaire as evidence and support when discussing how the participants have experienced the practices of the bilingual meetings. 


\section{Quantitative description of language use in the meetings}

The recordings from the meetings encompass 395 turns, of which 52\% (207) were monolingual and 48\% (188) bilingual. During these turns, Finnish was spoken for $53 \%$ of the time, and Swedish $47 \%$ of the time. This is one indication of the symmetrical relation between the two languages. Table 1 displays the number of monolingual and bilingual turns and the number of times the language is changed within the bilingual turns.

Table 1: Quantitative description of the language use according to the phase of the meeting

\begin{tabular}{lrrr}
\hline & Preliminary and closing actions & Processing issues & Total \\
\hline Turns & 64 & 331 & 395 \\
Monolingual turns & 29 & 178 & 207 \\
Bilingual turns & 35 & 153 & 188 \\
Changes within turns & 74 & 586 & 660 \\
Range & $1-5$ & $1-44$ & \\
Average & 2 turn & $4 /$ turn & \\
\hline
\end{tabular}

Most of the turns (331) occurred in the processing issues phase (see Table 1). The proportions of monolingual and bilingual turns in both phases of the meetings are quite balanced. With regard to the monolingual turns, there seems to be a difference between the use of Finnish and Swedish. The proportion of Finnish turns was considerably smaller (31\%) than Swedish turns (69\%). However, even though the difference in percentages is considerable, the difference in time is only a few minutes (30 minutes in Finnish and 33 minutes in Swedish). The explanation for this is that many of the turns in Swedish were short and lasted only 1-3 seconds. The most changes of language within a turn were 44, in an expert presentation, and on average, there were four changes per turn.

The answers to the questionnaire reveal that the meeting participants ( $N=21$; 43\% reporting Finnish as their mother tongue [Fmo], 57\% reporting Swedish as their mother tongue [Smo]) evaluated their knowledge of the other national language to be good. However, the productive language skills, writing and speaking, were not evaluated as highly as the receptive language skills (reading and listening comprehension). Sixty-seven percent of the Fmoinformants and $100 \%$ of the Smo-informants rated their receptive skills as good. In other words, the latter group reported that they could read and 
understand spoken Finnish without any problems. Fifty-six percent of the Fmoinformants judged their productive skills to be good, while the corresponding percentage among the Smo-informants was $83 \%$. One explanatory factor for the good language skills of the participants is that many of them hold official positions in a bilingual area. When a person is recruited for an official position within the state or bilingual municipal administration, it should be verified that his or her knowledge of languages meets the linguistic requirements for the work assignments. This is stated in the Act on the Knowledge of Languages Required of Personnel in Public Bodies (424/2003). The officials who are included in the meeting participants in this study must therefore have a solid command of both the national languages in order to be able to carry out their duties in the bilingual region of Ostrobothnia with a Swedish-speaking majority. In this context, the bilingual linguistic practices serve language political goals and simultaneously reflect shared social and societal values in which equal access and equal participation is highly regarded. This becomes evident through the use of meta-communicative utterances in the meetings (such as "briefly in Swedish" or "shall I translate").

In addition, respondents described the bilingual language practices of the meetings generally as functional (85\%, 18 persons), fair (90\%, 19 persons), and natural (80\%, 17 persons). However, repeating exactly the same things word-forword in two languages was considered unnecessary. On the other hand, the participants reported that it is not good if a speaker leaves out something relevant so that the whole picture of the issue ends up being substantially different in the two languages, and that it is disturbing if someone presents an issue unclearly only in one language. In addition, when asked whether they would prefer to have simultaneous interpretation in the meetings, three participants thought it necessary. Evidently, equality in language use in a meeting context can be achieved without using a lingua franca and without interpretation. Consequently, it seems that the major challenge in the meetings is finding a balance between repetition and omission when conducting a bilingual meeting within the timeframe of the meeting.

\section{Bilingual action as a characteristic of professional communication}

The following section addresses the types of bilingual action found in the material and how those interact with the ideal criteria of economy, precision, and efficiency. We will relate the criteria and the types of bilingual action to how 
the meeting participants experienced the linguistic practices in the meetings as expressed in their answers to the questionnaire. Finally, we will present the typology and discuss which types of communicative choices can be regarded as optimal in the structured institutional context of a bilingual formal meeting by delivering the same or different contents in both languages.

\subsection{Economic language use}

Of the three criteria of professional communication, economic language use has to do with the time used for getting something done. Two types of bilingual action seem to be especially connected with economic language use, summarizing monolingual talk in the other language (SMT) and text-based presenting in two languages (TBP). According to the participants, bilingual meetings are not ideal from the point of view of economic language use, since a majority of the participants at the meetings reported that using two languages slows down the meetings (62\%, 13 persons).

Using only one language instead of two is a controversial solution to the question of how to improve economy in a bilingual formal meeting. At the level of the paragraph, this solution is not applied in our material, but within the paragraphs, there may be some monolingual turns (e.g., in the discussion among the participants) as well as monolingual passages. These can also be summarized in the other language. The first type of bilingual action discussed here is summarizing monolingual talk in the other language (SMT). This summarizing might be done by the speakers themselves or by the chairperson. Within this type of bilingual action, monolingual talk can comprise several turns and TCUs, but the summarizing part is found in one turn and forms only one TCU.

For example, there is a case in the material in which a minor issue, a roundabout in a Swedish-speaking village, was presented by an expert only in Swedish, probably because it was deemed to be more relevant for that language group. This can be considered an economical use of the time for presenting the issue. However, from the point of view of the Finnish-speaking participants, it is not economical if they do not understand the relevant details and nuances, which may lead to questions and new discussions. Following the presentation, the chairperson summarized the content of the presentation in Finnish, making this communicative choice in order to present the relevant aspects of the matter in the other language as well. In this case, the economy aspect consists of a longer turn not being repeated but merely summarized in the other language. Again, the experience of what can be considered economic language use varies 
depending on the point of view. For the speaker, this type of action is economic, even though not necessarily satisfying if the chairperson does not correctly convey the focal points. For the chairperson it is not economic, and for the participants the experience depends on many factors, such as how the written documents support their understanding of the issue.

Example 1 illustrates a case in which the speaker himself summarizes in Finnish what he has first said in Swedish. The passage in example 1 stems from the second paragraph of two, relating to the processing of issues phase of the meeting. The processing of a paragraph that concerns cross-border cooperation projects funded by the EU takes 13 turns, of which the opening and closing turns by the chairperson are bilingual. The expert presentation was also bilingual and divided into two turns by a 9-turn-long discussion in the middle. The discussion between the expert, the chairperson and two participants proceeded in Swedish, except for one bilingual turn. The expert presented 18 monolingual, bilingual, and quadrilingual PowerPoint slides: ten were presented before or during the discussion and eight after it. The oral presentation itself consisted of 18 structural passages, of which 13 were bilingual and 5 monolingual ( 2 in Finnish, 3 in Swedish).

(1) Original

Sen har vi ett projekt som heter Sikens yngelproduktion kanske det ju heter det nånting, Intersik kallar de också. Där det då är det här föregående projekt, det kan ju säga det är då turistorganisationerna som är bakom det här, kommunerna och turistorganisationerna. Här är det då på finsk sida är det Vilt- och fiskeriforskningsinstitutet, på svenska sidan Länsstyrelsen i Umeå med i ett sånt här projekt för att se på hur sikbeståndet så ska behållas och bevaras och förbättras förutsättningarna för att siken ska kunna reproduceras ska förbättras. Det handlar mycket om att titta på ner i vattnet och se vad som finns där och var som är bra för fisken att leva. [SE] Tämä kalaprojekti Intersik on siinä on Riistaja kalataloudentutkimuslaitos täällä Vaasassa ja Västerbottenin lääninhallitus mukana ja koskee sitten siian tulevaisuutta, miten saatais pian siika lisääntymään ja säilymään täällä merialueella. [FI] (7.5.)

\section{Translation}

Then we have a project called the Production of whitefish fry, maybe it has another name, they also call it Intersik. About the previous project it should have been said that it is tourist organizations that are responsible for it, municipalities and tourist organizations. For this one, it is the Game 
and Fisheries Research Institute, on the Swedish side it is the County Administrative Board in Umeå that runs this kind of project to find out how the whitefish stock should be sustained and preserved and how the possibilities of whitefish to reproduce can be developed. What it involves is basically looking down into the water and seeing what there is and what is good for the fish to live in. [SE] This fish project Intersik has the Game and Fisheries Research Institute here in Vaasa and the County Administrative Board in Västerbotten involved and it concerns the future of whitefish, how to get whitefish to reproduce swiftly and preserve it in this part of the sea. [FI] (7.5.)

The example above illustrates how the content first presented in Swedish (TCU L1) was summarized in Finnish (TCU L2) at the end of the passage. There were pictures of fish on the Swedish-language PowerPoint slide accompanying the talk so that the topic of the passage became clear for everybody. The economy of the language used consists in choosing the relevant details for the summary in the Finnish part of the TCC: the name and aim of the project and the actors responsible for it. The Swedish part of the TCC contained hesitations and reparations and even an added comment to the previous passage not repeated in Finnish, which can be considered economical for those listening.

The second type of bilingual action that is relevant for economic language use is what we call text-based presenting in two languages (TBP). From the point of view of economic language use, the documents used as a basis for the presentation make it possible for the expert to presuppose some knowledge of the issue irrespective of the way of using language during the presentation. Similarly, the visual aids make it possible to leave out details that can be gleaned from the PowerPoint slides. Text-based presenting may be economical if the speaker lets the text convey some of the meanings and does not read aloud from the text, at least not in the same language.

The second example stems from the first issue processing paragraph of a total of six. The paragraph comprised 28 turns, of which the opening and closing turns by the chairperson were bilingual. The processing of the paragraph (on the financial details of an EU program) started with four preparatory turns, of which three were in Swedish and one was bilingual. The expert presentation was bilingual and was interrupted once by a short turn to express a comment given by a participant when requested by the expert. The expert presented 11 PowerPoint slides (7 bilingual and 4 monolingual in Finnish) in two turns containing ten bilingual and one monolingual Swedish passage. The presentation was followed by 20 discussion turns, of which two were bilingual and 18 in Swedish. 
(2) Original

$\mathrm{Nu}$ kommer vi Österbottens förbund då. [SE] Elikkä nyt tullaan niin ku Pohjanmaan liiton tilanteeseen, mikä Pohjanmaan liiton tilanne on. Pohjanmaan liitto on sitonu ja varannu yhteensä noin 8 miljoonan euron edestä rahoja hankkeisiin. Hankkeiden määrä 49. Keskimääräinen rahoituksen volyymi 166 000. Painopiste EAKR-ohjelmassa toimintalinja kakkosessa, 60 prosenttia rahoituksesta kohdistuu sinne. Hankkeiden toteutusaika noin kolme vuotta. [FI] Vi har avslutade projekt fyra stycken och många >av dom projekten som det här beviljades finansiering 20082009, så det har avslutats nu i året. En sån här sak som ministeriet är väldigt intresserad av att hur länge utbetalningsärendet ligger hos varje respektive myndighet. Hos oss tar behandlingen genomsnitt 67 dagar på Österbottens förbund, det här maksatushakemus, medan det genomsnittet i hela Finland är då 88, så vi är snabbare än de här då andra landskapsförbunden i Finland. Nånting positivt åt sökanden i alla fall. Bra. Följande sida. [SE] (11.2.)

\section{Translation}

Now we come to the Regional Council of Ostrobothnia. [SE] So, now we come in a way to the situation of the Regional Council of Ostrobothnia, to what the situation is with the Regional Council of Ostrobothnia. The Regional Council of Ostrobothnia has bound and reserved altogether about 8 million euro worth of money in projects. The number of projects is 49. The average volume for financing is 166000 . The focus is on the ERDF program in its line 2, 60\% of the financing is allocated there. The execution time is about 3 years. [FI] We have four finalized projects and many of those projects were allocated financing in 2008-2009, so those have ended this year. The ministry is very interested in how long the payment request stays at each authority. With us at the Regional Council of Ostrobothnia it takes in general 67 days to process, this [SE] payment application [FI], while the corresponding mean in whole Finland is 88 , so we are faster than those other regional councils in Finland. Something positive for the applicants in any case. Good. Next page. [SE] (11.2.)

The passage in the second example above is based on a bilingual PowerPoint slide with two columns, each with eight parallel points, in Swedish to the left and in Finnish to the right. The expert started the passage in Swedish and repeated the content of the TCU twice in Finnish, thus forming a TCC. Then he continued in Finnish and discussed the first five points on the PowerPoint slide in Finnish (TCU L1) before continuing with the rest of the points in Swedish (TCU L2). This type of text-based presentation is 
economical because the talk does not contain any repetition as the required information in the other language can be retrieved from the slide. Consequently, a TCC is not formed in this part of the passage. The expert made it easy for the participants to follow the presentation by mentioning the key terms and numbers.

As a bilingual action, text-based presenting of issues in two languages can take different forms that permit varied interpretations of what is economical. For example, if an expert speaks in one language and presents slides in the other language, it is economical from the expert's point of view. It is also possible that both the presentation and the PowerPoint slides are bilingual as in the second example above. The presentation can also fulfill the criteria of economy to varying degrees. A bilingual presentation in which language is changed very frequently and the same things are repeated can appear uneconomical in comparison to a presentation where there are longer stretches in one language because frequent repetition and changing language is tiring to listen to.

\subsection{Efficient language use}

The second criterion, efficiency, covers relevant, concise, and focused language use. In the bilingual meetings studied, two types of bilingual action seem to have a connection with efficient language use. These are choosing relevant information to convey in the other language (CRC) and excluding contextual information in the other language (ECI). In professional communication, efficiency is generally brought about by concentrating on relevant issues (see, e.g., the first example above where the name and aim of the project and the actors responsible for it were considered relevant). In the context of a bilingual formal meeting, choosing what is relevant is a key issue in both languages. It may well be that what is relevant depends on who is most affected by the issue. For example, in the case of the roundabout described above, the presentation was directed to the Swedish-speaking participants as the construction was to be carried out in a Swedish-speaking village. Therefore, the issue was described in more detail in Swedish by the expert and summarized in Finnish by the chair. Breaching the criterion of efficiency is exemplified in our material in two ways. First, when everything is repeated in both languages, no choice of what is relevant in the other language has been made, which is not efficient. Similarly, if too little is conveyed, the criterion of efficiency is not fulfilled.

In professional communication, contextual information can generally be relied on to create efficiency when the participants share the same 
background knowledge and situational factors. An exceptional case in our material is one turn in which a TCU was bilingual because of code-switching. The context was such that the expert stopped in the middle of the presentation to ask if the participants had any questions. At that point, a participant asked in Swedish if the expert could clarify the categories he had been describing bilingually in his own words, without using the terms, which were presented in Finnish in a table in the meeting documents. The expert answers bilingually, by saying the numbers of the categories in Swedish and reciting their names from the table in Finnish ("Ettan [SE] yritystoiminta [FI], tvåan [SE] innovaatiotoiminta [FI], trean [SE] saavutettavuus [FI], och fyran [SE] kaupunkialueet [FI]"). This type of code-switching was unusual in the meetings studied, and only $3 \%$ of turn-internal language changes concerned a word or a short phrase (insertion). In this example case, the expert was being efficient in his bilingual presentation, but the accompanying document was monolingual, which is why the participants could not follow his presentation because he did not use the proper terms.

In the bilingual formal meetings studied, excluding contextual information is used when the two languages used are intertwined with each other without repetition (as described in the example above). This type of bilingual action is not very common in the material because there is a strong tendency to keep the languages separate. It is also debatable whether this is efficient and preferable in every situation, because efficiency requires that the talk is understandable. What is more, this action is closely related to text-based presenting because it often requires the presence of a document or visual aid, but it is more efficient because there is no repetition to any direction.

\subsection{Precise language use}

The third criterion of ideal professional communication is precision, which in professional communication is often connected with ways of presenting a full depiction of the issues discussed for the participants. In our material, repeating in the other language (ROL) and adding new information in the other language (ANI) are directly related to precise language use. The third example (Example 3) illustrates those types of bilingual action use that serve the precision ideal. It is derived from a meeting with 8 paragraphs processing issues. The passage in the example stems from the seventh paragraph concerning the regional program for 2011-2014. There were 29 turns and the opening and closing turns by the chairperson were again bilingual. The 
expert presentation consisted of one turn, which was bilingual, and contained 9 passages ( 8 bilingual and 1 monolingual in Swedish) in connection with 8 PowerPoint slides ( 7 bilingual and 1 monolingual in Finnish) and one text document, a table in Finnish. The presentation was followed by 26 discussion turns of which 11 were bilingual, 10 were in Finnish, and 5 were in Swedish. The passage in example 3 is based on a PowerPoint slide presenting a figure with Finnish texts.

\section{(3) Original}

Sen sägs det också i lagen att vid behov tar vi upp samarbetsområdena för kommunerna inom regionen. [SE] Elikkä nyt uutena pykälänä tässä laissa on myös tämä, että tarvittaessa maakuntaohjelmaan kirjataan määrittelyalue kuntien yhteistyöalueista. [FI] Den här bilden visar oss den här processen för deltagande och bedömning och som ni ser, så det är riktigt omfattande. [SE] Elikkä tämä on osallistumis- ja arviointisuunnitelma ja kuten näette, tämä prosessi on erittäin kattava. [FI] Och eftersom vi hade inte så mycket tid att för det här utarbetande, så konstaterade styrelsen och fattade beslut att samtidigt började man att utarbeta både landskapsöversikt och landskapsprogram. [SE] Elikkä tän kiireellisen valmisteluaikataulun mukaan, takia, niin maakuntahallitus teki päätöksen, että aloitimme maakuntasuunnitelman ja maakuntaohjelman valmistelun samanaikaisesti. [FI] Och nu är det så att som vi har märkt kanske eller hoppas att ni har märkt också den här kungörelsen att det landskapsprogram är framlagt. [SE] Elikkä nyt toivon, että olette ehkä huomanneet tämän meidän kuulutuksemme, jonka mukaan niin meidän maakuntaohjelma on tällä hetkellä lausunnolla. [FI] Och tiden går ut 23. alltså på nästa vecka. [SE] Elikkä tämä kuulutusaikahan loppuu ensi viikolla 23. päivä. [FI] Och jag tror att fortfarande orkar kommuner och alla andra intressenter vara mycket aktiva. [SE] Eli mä uskon, että meidän kaikki kunnat ja muut sidosryhmämme jaksavat yhä edelleen olla aktiivisia. [FI] Och det har varit riktigt positivt att så många har deltagit i den här själva processen och ännu orkar fundera. [SE] Elikkä kunnat on vieläkin erittäin aktiivisia ja jaksavat tuota miettiä maakuntamme tulevaisuutta. [FI] (16.4.)

\section{Translation}

Then it is also stated in the law that if needed we will note the cooperation areas for municipalities within the region. [SE] So now as a new paragraph in this law is also this that if needed even a specification of the cooperation areas for municipalities will be noted in the regional plan. [FI]This slide shows us this process of participation and evaluation and as you see, 
it is very extensive. [SE] So this is a plan for participation and evaluation and as you see this process is very extensive. [FI] And because we did not have so much time to work on it, so the council stated and decided that we would start working on both the regional plan and the regional program at the same time. [SE] So according to this busy schedule for the preparation, because of it, the regional council decided that we will start the preparation of the regional plan and the regional program simultaneously.[FI] And now it is as we have noticed maybe, or hope that you have noticed also this announcement that the regional program is ready for comments. [SE] So now I hope that you maybe have noticed our announcement, according to which our regional program is at this moment ready to be commented. [FI] And the time runs out on the 23rd, that is next week. [SE] So this time for comments runs out next week on the 23rd. [FI] And I think that municipalities and other interested parties still feel up to being very active. [SE] And it has been really positive that so many have participated in the process itself and still feel up to reflecting. [SE] So the municipalities are still very active and have the strength to reflect on the future of our region. [FI] (16.4.)

It might seem natural on the basis of a monolingual bias that the same thing should be said in two languages in bilingual formal meetings. In our material repetition is prominent in openings and closings both at the level of the whole meeting and at the level of a paragraph. Even in expert presentations, some experts make the communicative choice of trying to say the same thing in both languages. Example 3 contains seven TCCs and 14 TCUs in one passage, which no doubt fosters precision, but this kind of repetition is both exhausting and irritating for the meeting participants. Irritation might be caused by the impression that the speaker is reading aloud both the original and a translation without variation, rather than addressing the audience.

Another type of bilingual action closely related to precision can be found in cases when a person presents something in one language and continues speaking in the other language, but not only repeats what was said but also adds new information or relevant details. We call this adding new information in the other language (ANI). Example 4 stems from the same paragraph as example 1, but from a passage presented before the 9-turn-long discussion, after which the expert continued with what was said in example 1.

\section{(4) Original}

Rahotus on tän näkönen. Meillä on rahaa EU:lta 30,5 miljoonaa euroa tälle seitsemän vuoden jaksolle. Saman verran tulee Ruotsista ja Suomesta 
kansallista rahaa ja tän kansallisen rahan Suomen osuudesta voin mainita sen, että se kulkee Pohjanmaan liiton kautta. Koko rahoitus on nyky, tai on tässä ohjelmassa kanavoitu Pohjanmaan liiton kautta. Että Pohjanmaan hallitus käsittelee tätä valtion vastikerahoitusta. Norjasta tulee sitten jonkun verran valtionrahaa ja alueellista rahaa. Yhteensä siis 66 miljoonaa pyörii tässä koko hommassa. Pohjanmaahan on jaettu kolmeen toimintalinjaan, joka näkyy tässä. [FI] Det här finansiering av programmet då är det såna att EU har då beviljat 30,5 miljon euro för 7 års period och det förutsätter då att finska och svenska stater, Finland och Sverige kommer in i nationella pengar de behöver inte vara statliga pengar alltihopa och inte heller är statliga pengar alltihopa. Lika mycket ska det vara sådana pengar och sen ska Norge har kommit in med en ganska blygsamt summa pengar, och totalt är det 66,64 miljoner euro. Det där programmet då, jag går inte till detaljerna, är indelat i tre stycken prioriteter, så av de här pengarna nu då har vi av EU-pengarna åtminstone, också de här nationella, statliga pengarna, också de här norska pengarna. Man kan säga att av alla pengarna så är det då ungefär 33 miljoner euro, lite mera också uppbundet i projekt. Jag ska återkomma till att det kanske inte ser lika bra ut på utbetalningssidan. Men det beror (på var sin fokus.) [SE] (7.5.)

\section{Translation}

This is how the financing looks like. We have money from the EU for 30.5 million euro for this 7 year period. Sweden and Finland endow an equal sum of national money, and concerning the Finnish part of the national money I can add that it goes through the Council of Ostrobothnia. All the financing is now or is in this program funneled through the Council of Ostrobothnia. So the board of Ostrobothnia will discuss these national matching funds. Then there is some national as well as regional money coming from Norway. In total, it is 66 million that is in question in this whole business. Ostrobothnia has been divided into three priority axes, which can be seen here. [FI] This financing of the program is such that the EU has allocated 30.5 million euro for a period of 7 years, and it is required that the Finnish and Swedish states, Finland and Sweden co-finance it with national money, it does not need to be government money altogether, and it is not government money altogether. There should be equal sums of that type of money and then Norway has allotted a rather small sum of money, and in total it is 66.64 million euro. The program then, I won't go into details, has been divided into three priority axes, for the EU money at least, and even for the national government money and also for the 
Norwegian money. One could say that of all the money, it is about 33 million euro which is tied in projects. I will return to this, it maybe does not look as good when it comes to the payment side. But it depends (on each priority). [SE] (7.5.)

The passage relates to a table presented in Finnish describing the financing of the three priority axes in detail. Although the expert mainly focused on the sums in the table in both TCUs (L1 and L2), he added new ideas as they occurred to him while speaking in one language or the other, but did not repeat everything in both languages. Therefore, the TCC is more than the sum of its parts. This type of bilingual action results in a high degree of precision, especially for those participants who understand both languages. The result derived from the questionnaire, that using two languages makes the discussion of the issues more versatile (67\%), can be assumed to be connected with this way of bringing in new ideas in the other language. The details added in Swedish (TCU L2) are marked with italics in the example.

\subsection{Typology}

Having analyzed our material in the light of the chosen three criteria of ideal professional communication, we summarize our findings in a typology of bilingual action (see Table 2) and discuss how the ideal criteria relate to each other in order to surmise what type of bilingual action might be optimal in this kind of professional context.

Table 2: Typology of bilingual action in relation to economy, efficiency, and precision

\begin{tabular}{lll}
\hline Economy & Efficiency & Precision \\
\hline $\begin{array}{l}\text { Summarizing monolingual } \\
\text { talk in the other language } \\
\text { (SMT) }\end{array}$ & $\begin{array}{l}\text { Choosing relevant information to } \\
\text { convey in the other language (CRC) }\end{array}$ & $\begin{array}{l}\text { Repeating in the other } \\
\text { language (ROL) }\end{array}$ \\
$\begin{array}{l}\text { Text-based presenting in two } \\
\text { languages (TBP) }\end{array}$ & $\begin{array}{l}\text { Excluding contextual information } \\
\text { in the other language (ECI) }\end{array}$ & $\begin{array}{l}\text { Adding new information in } \\
\text { the other language (ANI) }\end{array}$ \\
\hline
\end{tabular}

Table 2 shows the six types of bilingual action identified in our material. These types are not exclusive but interact closely depending on the context. In bilingual contexts without interpretation, the speakers need to make communicative choices on the degree to which the same content must be delivered in two languages, and the typology of bilingual action can also be related to this. 
If the speaker chooses to try to say the same thing in both languages, the bilingual action to select would be repeating the content in the other language (ROL). This leads to a high degree of precision and the result resembles a combination of two monolingual meetings. Although this type of action is used at the level of a passage, it is more common for the experts to settle for only partly saying the same thing in the two languages. The bilingual action in this case is choosing the relevant information (CRC) which is both more economical and efficient and more convenient for the participants. When examined on the basis of the similarity of content in the two languages, choosing relevant information is a superordinate concept for summarizing monolingual talk in the other language (SMT), excluding contextual information in the other language (ECI) and adding new information in the other language (ANI). This conceptual relationship also illustrates how the criteria for successful professional communication are intertwined. In addition, symmetry between two languages requires that there is some variation in which language comes first at the level of a TCU, in other words, which is the summarizing language, the adding language, and the excluding language. In addition, the speakers also have the option of delivering different content in the two languages. However, this choice normally requires textual support, such as visual aids, most often PowerPoint slides, and meeting documents. In text-based presenting (TBP), it is the textual support that makes a functioning professional communication not only possible but also economical in bilingual formal meetings.

\section{Conclusion}

This article aimed to explore how linguistic resources from two local languages used in expert presentations in bilingual formal meetings function with respect to the three ideal criteria of professional communication: economy, efficiency, and precision. Expert presentations were chosen because they represent the core of professional communication in formal meetings and take up a large proportion of the meeting time. These features make the presentations central to ensuring the meeting participants understand the issues discussed. We have used the term bilingual action to describe the communicative choices that the chairperson and experts make when they use two languages in a way that makes professional communication functional. Based on the results, we have suggested a typology of bilingual action for bilingual formal meetings.

In the context of the whole meeting, an unwritten but commonly accepted objective seems to be to maintain a balance between the two languages. The driver for this objective is the balanced relation between the two languages within the 
region, but also legal and language ideology factors. The results of the study reveal a wide variety of ways of using two languages in expert presentations. The most common communicative choice for the experts was to speak in two languages and utilize PowerPoint slides and text documents in two languages in support. However, there are other alternatives including speaking in one language and showing slides in the other, while supported by text in the agenda in two languages, or speaking in one language and having bilingual slides. In some cases, the chair may summarize the expert presentation in the other language. The creative combinations of different semiotic resources used in multilingual professional communication in order to reach the goals of economy, efficiency and precision has not been fully explored and might offer an avenue for further research.

It is often said that bilingual solutions are time-consuming. Still the bilingual meetings in our material seem to be shorter than their monolingual counterparts in other regions. According to a preliminary Internet search of the minutes of ten corresponding monolingual meetings in different regions during 2010-2011, the mean length of the corresponding monolingual meetings was approximately 2 hours compared with one and a half hours for the bilingual meetings. One explanation for this might be found in the types of bilingual action. When the situation is bilingual, the requirements for economy and efficiency are paramount, which may lead to shorter meetings overall. Consequently, it seems that being precise cannot be the ultimate goal, because it tends to be in conflict with both efficiency and economy. As for efficiency, being able to quickly decide what is relevant in the context in question is an important skill for professionals who function in bilingual contexts.

The findings of this study suggest that total precision at the level of TCC is not feasible in bilingual formal meetings, as it tends to conflict with both economy and efficiency. The ideal of economy governs communicative choices so that the timeframe set for the meeting is respected, whereas efficiency requires a judgment of relevance, which is a core skill for professionals. Moreover, the study reveals that bilingual action is based on intuitive solutions by the experts and not on a written policy or agreed guidelines at an organizational level. The approach can function well, as long as the meeting participants have shared values and experience of corresponding situations. However, if new participants enter the context, they may be confused because the tacit knowledge is not documented, and they have to learn by trial and error. As Skårup (2004: 43) points out, it is important who the members of a multilingual community of practice are, because if some people leave, the community might stop being bilingual.

The typology of bilingual action suggested in this article can be used when introducing the practices of bilingual meetings to new participants. All in all, these practices always reflect the societal, situational, social and individual 
factors, which are intertwined in complex ways. At the societal level, legislation together with the balanced linguistic situation in the region support bilingual practices. Simultaneously, at the situational level the issues discussed may concern one language group more than the other, which may lead to other types of practices, even monolingual ones. The social factors such as codes of conduct, relationships between participants and especially the way the chairperson functions in two languages affect the ways in which the experts balance between what is economical, efficient, and precise during the meetings. Finally, individual factors such as the mother tongue and language proficiency of the participants as well as the participants' motivation and interest toward the issues influence the dynamics of the discussions conducted and their linguistic realizations.

The present findings underline the importance of documentation and open discussion of organization-level practices in guiding bilingual action as an intentional and goal-oriented practice in professional contexts. The types of bilingual action presented in this article aim to create a symmetrical relationship between two local languages used in the same context. However, they might still suggest alternate ways of using bilingual and multilingual linguistic resources in professional communication in more asymmetrical contexts. This area warrants further research.

\section{References}

Act on the Knowledge of Languages Required of Personnel in Public Bodies, 424/2003.

Retrieved 2014-6-1, from http://www.finlex.fi

Angouri, Jo. 2014. Multilingualism in the workplace: Language practices in multilingual contexts. [Special Issue]. Multilingua 33(1-2). 1-9.

Angouri, Jo \& Meredith Marra. 2010. Corporate meetings as genre: A study of the role of the chair in corporate meeting talk. Text \& Talk 30(6). 615-636.

Asmuss, Birte \& Jan Svennevig. 2009. Meeting talk: An introduction. Journal of Business Communication 46(1). 3-22.

Bargiela-Chiappini, Francesca \& Susan Harris. 1997. Managing language. The discourse of corporate meetings. Amsterdam: Benjamins.

Boden, Deirdre. 1994. The business of talk. Organizations in action. Cambridge, MA: Polity. Creese, Angela, Adrian Blackledge, Taşkin Baraç, Arvind Bhatt, Shahela Hamid, Li Wei, Vally Lytra, Peter Martin, Chao-Jung Wu \& Dilek Yağcioğlu. 2011. Separate and flexible bilingualism in complementary schools: Multiple language practices in interrelationship. Journal of Pragmatics 43(5). 1196-1208.

Drew, Paul \& Marja-Liisa Sorjonen. 1996. Institutional dialogue. In Teun Adrianus van Dijk (ed.), Discourse: A multidisciplinary introduction, 191-216. London: Sage.

Duncan, Starkey. 1972. Some signals and rules for taking speaking turns in conversations. Journal of Personality and Social Psychology 23(2). 286-288. 
Engberg, Jan. 1998. Introduktion til fagsprogslingvistikken. Århus: Forlaget Systime.

Fishman, Joshua A. 1972. The sociology of language. In Pier Paolo Giglioli (ed.), Language and social context: Selected readings, 45-58. Harmondsworth: Penguin.

Fluck, Hans-Rüdiger. 1991. Fachsprachen. Tübingen: Narr.

Ford, Cecilia E. \& Sandra A. Thompson. 1996. Interactional units in conversation: Syntactic, intonational, and pragmatic resources for the management of turns. In Elinor Ochs, Emanuel Abraham Schegloff \& Sandra Annear Thompson (eds.), Interaction and grammar, 134-184. Cambridge, MA: Cambridge University Press.

Ford, Cecilia E., Barbara A. Fox \& Sandra A. Thompson. 1996. Practices in the construction of turns: The "TCU" revisited. Pragmatics 6(3). 427-454.

Gafaranga, Joseph. 2000. Language separateness: A normative framework in studies of language alternation. Estudios de Sociolingüística 1(2). 65-84.

Giles, Howard, Richard Yvon Bourhis \& Donald Taylor. 1977. Towards a theory of language in ethnic group relations. In Howard Giles (ed.), Language, ethnicity and intergroup relations, 307-348. London: Academic Press.

Gunnarsson, Britt-Louise. 2014. Multilingualism in European workplaces. [Special Issue]. Multilingua 33(1-2). 11-33.

Ishida, Hiroji. 2006. Learners' perception and interpretation of contextualization cues in spontaneous Japanese conversation: Back-channel cue Uun. Journal of Pragmatics 38. 1943-1981.

Jan, Jariad Mohd. 2003. Code-switching for power wielding: Inter-gender discourse at the workplace. Multilingua 22(1). 41-57.

Jefferson, Gail. 1983. Two explorations of the organization of overlapping talk in conversation. Tilburg papers in language and literature. No 28. Tilburg University.

Koskela, Merja. 2002. Ways of representing specialized knowledge in Finnish and Swedish science journalism. LSP \& Professional Communication 2(1). 27-39.

Liebkind, Karmela, Marika Tandefelt \& Tom Moring. 2007. Introduction: Why a special issue on the Swedish-speaking Finns? International Journal of the Sociology of Language 187/188. 1-11.

Linell, Per \& Lennart Gustavsson. 1987. Initiativ och respons. Om dialogens dynamik, dominans och koherens. Linköpings universitet. Tema Kommunikation. SIC 15.

Mondada, Lorenza. 2004. Ways of "doing being plurilingual" in international work meetings. In Rod Gardner \& Johannes Wagner (eds.), Second language conversations, 18-39. London: Continuum.

Mougeon, Raymond \& Edouard Beniak. 1994. Bilingualism, language shift, and institutional support for French: The case of the Franco-Ontarians. International Journal of the Sociology of Language 105/106. 99-126.

Nikko, Tuija. 2009. Dialogic construction of understanding in cross-border corporate meetings. Acta Universitatis Oeconomicae Helsingiensis A-351. Helsinki: Helsinki School of Economics dissertation.

Pilke, Nina \& Sanna Salminen. 2013. Kielelliset käytänteet Pohjanmaan maakunnan yhteistyöryhmän (MYR) kaksikielisissä kokouksissa: Tilannesidonnainen samanaikaisuus ja kielivalinnan vaihtoehtoisuus viestinnän ja vuorovaikutuksen näkökulmasta. Vaasan yliopiston julkaisuja. Selvityksiä ja raportteja 183. Vaasa.

Pohjanmaa lukuina. 2013. Population by language at end-2012. Retrieved 2014-6-25, from http://www.pohjanmaa.fi/medialibrary/data/Kielirakenne_2012-\%7Bxsvxk-g65ii- gdj1p\% 7D.pdf 
Sacks, Harvey, Emanuel Schegloff \& Gail Jefferson. 1974. A simplest systematics for the organization of turn-taking for conversation. Language 50(4). 696-735.

Schnurr, Stephanie. 2013. Exploring professional communication: Language in action. London: Routledge.

Schwartzman, Helen B. 1989. The meeting: Gatherings in organizations and communities. New York: Plenum.

Selting, Margret. 2000. The construction of units in conversational talk. Language in Society 29(4). 477-517.

Skårup, Terkel. 2004. Brokering and membership in a multilingual community of practice. In R. Gardner \& J. Wagner (eds.), Second language conversations, 40-57. London: Continuum.

Taboada, Maite \& Loreley Hadic Zabala. 2008. Deciding on units of analysis within centering theory. Corpus Linguistics and Linguistic Theory 1. 63-108.

The Language Act of Finland, 423/2003. Retrieved 2014-6-25, from http://www.finlex.fi

Vasilev, George. 2013. Preaching to the choir or converting the uninitiated? The integrative potential of in-group deliberations. Critical Review of International Social and Political Philosophy 16(1). 109-129.

White, Ron. 1997. Back channeling, repair, pausing and private speech. Applied Linguistics 18(3). 314-344. 
Copyright of Multilingua is the property of De Gruyter and its content may not be copied or emailed to multiple sites or posted to a listserv without the copyright holder's express written permission. However, users may print, download, or email articles for individual use. 